\title{
Mass production of entomopathogenic fungi using agricultural products and by products
}

\author{
K. Sahayaraj and S. Karthick Raja Namasivayam \\ Crop Protection Research Centre, St.Xavier's College, Palayamkottai 627002, Tamil Nadu, Department of \\ Biotechnology and Bioinformatics, SRM University Ram, Apuram campus, Chennai 89, India.
}

Accepted 8 January, 2008

\begin{abstract}
Various agricultural products and by products such as grains, vegetable wastes, seeds, rice husk, saw dust and liquid media such as coconut water, rice and wheat washed water and rice cooked water were evaluated for mass production of three entomopathogenic fungi; Beauveria bassiana, (Bals.) Vuil. Paecilomyces fumosoroseus (Wize) Brown and Smith and Verticillium lecanii. (Zimm) Viegas. Among the grains, wheat supported maximum spore production for $B$. bassiana while sorghum recorded maximum spore production in $P$. fumosoroseus and $V$. lecanii. Similarly carrot, jack seeds and ladies finger also supported good growth and sporulation of all the three tested fungi. Coconut water supported maximum growth and sporulation.
\end{abstract}

Key words: Entomopathogenic fungi, mass production, agricultural products.

\section{INTRODUCTION}

Biopesticides based on bacteria, viruses, entomopathogenic fungi and nematodes are often considerable scope as plant protection agents against several insects (Noris et al., 2002). Use of entomopathogenic fungi as biological control agents for insect species has increased the global attention during the last few decades. The mycoinsecticide based on Beauveria bassiana (Balsamo) Vaillemin (Babu et al., 2001; Sharma, 2004), Paecilomyces fumosoroseus (Wize) Brown and Smith (Alter and Vandenberg, 2000; Avery et al., 2004) and Verticillium lecanii (Zimm.) Viegas (Butt et al., 2001) have been used to control various insect pests

Production of adequate quantities of a good quality inoculum is an essential component of the biocontrol programme. The production of entomopathogens may be taken up by the following methods based on the quantity of the product desired: 1 ) relatively small quantities of the inoculum for laboratory experimentation and field-testing during the development of mycopesticide and 2) development of a basic production system for large-scale production by following the labour intensive and economically viable methods for relatively small size markets. China (Feng et al., 1994) and America (Alves and Pereira,

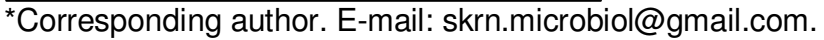

1989) supply fungal pathogens by this method in sufficient quantities for niche markets in their immediate area. Development of simple and reliable production system follows the basic multiplication procedures of submerged liquid fermentation for the production of blastospores, which are short lived, and hydrophilic (Romback, 1989) or solid state fermentation (Rousson et al., 1983) for the production of aerial conidia. However, the most viable mass production technologies include making use of a diphasic strategy in which the fungal inoculum is pro-duced in liquid culture, which is further utilized for inoculating the solid substrate(s) for conidia production (Burges and Hussey, 1981). The present study was undertaken to evaluate grains such as rice, wheat, raghi, sorghum, pearl miket and maize at different tempera-tures, and liquid media such as rice washed water, wheat washed water, coconut water and rice cooked water and naturally available solid media such as carrot, ladies finger, jack seeds, rice husk, and saw dust for the mass production of $B$. bassiana, $P$. fumosoroseus and $V$. lecanii.

\section{MATERIALS AND METHODS \\ Entomopathogenic fungal culture}

$B$. bassiana and $P$. fumosoroseus were isolated from the diseased 
caterpillar of $S$. litura collected from the groundnut fields in Tamil Nadu, India. The diseased larvae showed white colour for $B$. bassiana and slight reddish mycelial surface growth for $P$. fumosoroseus. The diseased larvae were collected in screw cap vials (18 $x 4 \mathrm{~mm}$ ) and brought to the laboratory for further studies. The diseased larvae were surface sterilized with $0.1 \%$ mercuric chloride for few seconds and then thoroughly washed with sterilized double distilled water. The excess water was removed by keeping the diseased larvae on Whatman filter paper No. 1. The diseased larvae were then cut into small pieces with the help of sterile blade and the bits were aseptically transferred on to the sabourand maltose agar enriched with $1 \%$ yeast extract (SMYA) slants with the help of sterile inoculation needle. The slants were kept at $25 \pm 1^{\circ} \mathrm{C}$. Diseased larvae were also kept on moist filter paper in Petri dish for mycelial growth and sporulation. The fungi were identified based on the morphological character as per Humber (1997). The identified fungi were $B$. bassiana (Balsoma) Vuillemin and $P$. fumosoroseus (Wize) Brown et Smith, V. lecanii (Zimm). Viegas was obtained from Microbial Type Culture Collection (MTCC 915) Chandigarh, India. All the cultures were maintained on SMYA and PDA slants

\section{Whole grain media}

Six whole grains viz rice, wheat, raghi, sorghum, pearl millet and maize were used for estimating the sporution of $B$. bassiana, $P$. fumosoroseus and $V$. lecanii at $28^{\circ} \mathrm{C}$. $100 \mathrm{~g}$ of each grain was washed well and soaked in water overnight except rice and pearl millet which were soaked for 2 - $3 \mathrm{~h}$ prior to starting the experiments. The excess water was drained by decanting and shade drying it for half an hour to further remove the excess moisture. Three replications were maintained for each grain. The grains were packed separately in individual $500 \mathrm{ml}$ bottle for $P$. fumosoroseus and $V$. lecanii and $500 \mathrm{ml}$ conical flask for $B$. bassiana separately. They were plugged with cotton wool and auto calved at 15 psi for 1 h. After cooling, $1 \mathrm{ml}$ of the spore suspension of fungal pathogen was inoculated into each bottle, separately. All these procedures were done under laminar air flow chamber. They were incubated in BOD incubator at $26,28,30$ and $32^{\circ} \mathrm{C}$ separately for 15 days. To avoid clumping, after 7 days of inoculation, the flasks and bottles were shaken vigorously to separate the grain and to break the mycelial mat. After 15 days of incubation, $10 \mathrm{~g}$ homogenous grain sample drawn from each replicate uniformly sperulating bottle/flasks was transferred to $100 \mathrm{ml}$ sterilized distilled water containing Tween $80(0.05 \%)$ solution in $250 \mathrm{ml}$ conical flasks. The flasks were shaken in mechanical shaker for $10 \mathrm{~min}$. The suspension was filtered through double layered muslin cloth. Counting of spores were made after the serial dilution of the suspension using double ruled Neubauer haemocytometer for determining the number of conidia in $1 \mathrm{~g}$ of the cereal grains.

\section{Liquid media}

Liquid media; rice wash water, wheat wash water, coconut water and rice cooked water were evaluated for the growth and sporulation of three tested fungi. $100 \mathrm{ml}$ of each medium was poured in $250 \mathrm{ml}$ capacity conical flasks and autoclaved at 15 psi pressure for $20 \mathrm{~min}$. Five flasks of each medium was inoculated with $1 \mathrm{ml}$ of spore suspension of each fungi separately and incubated at $28^{\circ} \mathrm{C}$ for 15 days. The spore suspension was subjected to spore counting and it was carried out as described in the previous section.

\section{Solid media}

Non-synthetic solid media; carrot, ladies finger, jack seeds, rice husk, and saw dust were tested. $100 \mathrm{~g}$ of each solid material was taken in $500 \mathrm{ml}$ conical flasks, inoculated with $1 \mathrm{ml}$ of spore suspension and incubated at $28^{\circ} \mathrm{C}$ in BOD incubator for 15 days. The spore count was made as mentioned earlier.

\section{Statistical analysis}

ANOVA was used to analyse the significance of temperature and media on sporulation of fungal pathogens using 'STATISTICA' computer package.

\section{RESULTS AND DISCUSSION}

In the present study, several naturally available substrates of both solid and liquid media were tested for mass multiplication of $B$. bassiana, $P$. fumosoroseus and $V$. lecanii. The success of microbial control of insect pests depends not only on the isolation, characterisation and pathogenicity, but also on the successful mass production of the microbial agents in the laboratory. Large-scale availability of the pathogen is a primary requirement in the bio-control programme. For a successful integrated pest management programme, the agents like the entomopathogenic fungi should be amenable to easy and cheap mass multiplication.

\section{Grains}

The results (Table 1) showed that among the grains tested, $B$. bassiana spore production was significantly higher on wheat $\left(11.76 \times 10^{10}\right)$. The spore count recorded at the respective temperatures on rice was slightly lesser than wheat. But the statistical composition between the wheat and rice were insignificant. In the case of $P$. fumosoroseus, sorghum recorded the highest spore count of $10.37 \times 10^{11} / 100 \mathrm{~g}$. Sorghum was found to be ideal for the mass production of $V$. lecanii; it recorded $11.31 \times 10^{10}$ spores $/ 100 \mathrm{~g}$. Pearl millet was found to be the next best media for the spore production $\left(10.17 \times 10^{10}\right.$ spores $/ 100$ g). The lowest spore production was recorded in maize (Table 1) which was statistically insignificant $(P>0.05, P$ $=0.071$ ).

Grains are cheap, easily available and act as best neutritive media for the mass multiplication of many micro and macro organisms. According to Ibrahim and Low (1993) and Sharma et al. (2002), rice was found to be the suitable media for the mass culture of $B$. bassiana. This cereal was also used for the mass production of other deuteromycete fungi. Gopalakrishnan et al. (1999) reported that sorghum was the ideal cereal for the mass production of Paecilomyces farinosus. In the case of $V$. lecanii, sorghum was found to be the ideal cereal for mass production, which is in confirmation with the findings of Lakshmi et al. (2001). Lowest spore production was recorded in maize at all temperatures. 


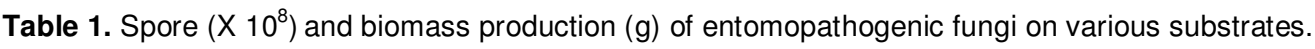

\begin{tabular}{|c|c|c|c|c|c|c|}
\hline \multirow{2}{*}{ Media } & \multicolumn{3}{|c|}{ Spore count $\left(\times 10^{8}\right)$} & \multicolumn{3}{|c|}{ Biomass (g) } \\
\hline & $\mathrm{Bb}$ & Pf & VI & $\mathrm{Bb}$ & Pf & VI \\
\hline \multicolumn{7}{|l|}{ Grains } \\
\hline Rice & 11.24 & 8.76 & 8.43 & 0.11 & 0.19 & 0.13 \\
\hline Wheat & 11.76 & 9.71 & 9.13 & 0.19 & 0.43 & 0.39 \\
\hline Sorghum & 10.24 & 10.37 & 11.31 & 0.41 & 0.41 & 0.51 \\
\hline Pearl millet & 9.78 & 10.26 & 10.17 & 0.47 & 0.45 & 0.54 \\
\hline Raghi & 10.72 & 10.17 & 9.76 & 0.64 & 0.61 & 0.67 \\
\hline Maize & 9.44 & 10.11 & 7.54 & 0.56 & 0.21 & 0.19 \\
\hline \multicolumn{7}{|c|}{ Non synthetic liquid media } \\
\hline Coconut water & 12.10 & 10.17 & 5.27 & 0.61 & 0.71 & 0.51 \\
\hline Rice cooked water & 10.21 & 2.12 & 2.11 & 0.58 & 0.44 & 0.28 \\
\hline Rice wash water & 8.76 & 6.75 & 3.12 & 0.51 & 0.54 & 0.46 \\
\hline Wheat wash water & 8.17 & 7.31 & 1.21 & 0.49 & 0.58 & 0.14 \\
\hline \multicolumn{7}{|c|}{ Non synthetic solid media } \\
\hline Carrot & 10.76 & 9.12 & 2.17 & 0.73 & 0.56 & 0.24 \\
\hline Jack seeds & 9.81 & 6.12 & 4.11 & 0.64 & 0.50 & 0.48 \\
\hline Ladies finger & 9.17 & 5.17 & 3.12 & 0.59 & 0.47 & 0.46 \\
\hline Rice husk & 6.31 & 1.21 & 1.27 & 0.24 & 0.41 & 0.15 \\
\hline Saw dust & 0.17 & 1.76 & 0.69 & 0.19 & 0.42 & 0.10 \\
\hline
\end{tabular}

$\mathrm{Bb}=$ Beauveria bassiana; $\mathrm{Pf}=$ Paecilomyces fumosoroseus $; \mathrm{VI}=$ Verticillium lecanii.

\section{Liquid media}

Among the liquid media, coconut water produced significantly higher spore production in all tested fungi. $\left(5.27 \times 10^{8}, 10.17 \times 10^{8}\right.$ and $5.27 \times 10^{8}$ spores $\left./ 100 \mathrm{ml}\right)$ and $0.51,0.71$ and $0.51 \mathrm{~g}$ of biomass production was recorded in $B$. bassiana, $P$. fumosoroseus and V. lecanii, respectively. The other media also supported spore production in all tested fungi (Table 1). Dangar et al. (1991) also observed similar findings in $M$. anisepliae. Abundance of glucose and minerals in the coconut water may enhance the growth and spore production of fungi. Rice and wheat washed water also supported the growth and sporolation of all the three tested fungi. Patel et al. (1990) reported that the purified rice wash water gave the best spore count in M. anisepliae.

\section{Solid media}

Among the seeds, vegetables and solid wastes such as rice husk and saw dust tested, $B$. bassiana recorded the maximum spore production $\left(10.76 \times 10^{8}\right.$ spores $/ 100 \mathrm{~g}$ with $0.73 \mathrm{~g})$ on carrot followed by jack seeds $(P<0.005$, $P=0.006)$. Carrot waste also supported maximum spore as well as biomass production of $P$. fumosoroseus (Table 1). In V. lecanii, jack seeds produced significantly $(4.11 \mathrm{x}$ $\left.10^{8}\right)$ higher spores $(P<0.05)$ followed by the ladies finger. Carrot also recorded $2.17 \times 10^{8}$ spores $/ 100 \mathrm{~g}$ and $0.24 \mathrm{~g}$ of biomass production and $1.27 \times 10^{8}$ spores $/ 100$ $\mathrm{g}$ was recorded in rice husk. However, V. lecanii pro- duced more and the least spores as well as biomass on jack seeds and sawdust, respectively (Table 1).

Gopalakrishnan and Mohan (2001), Gopalakrishnan et al. (1999) and Tincilley et al. (2000) reported that carrot was found to be the cheapest and best suitable media for the large-scale production of deuteromycete fungi. Jack seeds also act as ideal media for the mass production of $B$. bassiana and V. lecanii. Santhanam et al. (1981) reported that jack seeds act as best media for the mass production of $V$. lecanii. Rich husk also supported the growth and sporulation. Puzari et al. (1997) reported that rice husk supplemented with $2 \%$ dextrose solution recorded more sporulation of $M$. anisopliae.

From the study it was clear that all the tested fungi were able to grow on a wide variety of agriculture products and by products of both solid and liquid state and this can be useful to farmers to culture these fungi easily.

\section{REFERENCES}

Alter JA, Vandenberg JJD (2000). Factors that Influencing the Infectivity of Isolates of Paecilomyces fumosoroseus Agains Diamond Back Moth, J. Invertebr Pathol., 78: 31-36.

Alves SB, Pereira RM (1989). Production of Metarhizium anisopliae and Beauveria bassiana, Ecosustania 14: 188-192.

Avery PB, Faulla J, Simmands MSJ (2004). Effect of Different Photoperiods on the Infectivity and Colonization of Paecilomyces fumosoroseus, J. Insect Sci. 4: 38.

Babu V, Murugan S, Thangaraja P (2001). Laboratory Studies on the Efficacy of Neem and the Entomopathogenic Fungus Beauveria bassiana on Spodoptera litura". Entomology, 56: 56-63. 
Burges AD, Hussey NW (1981). Microbial Control of Insect Pests and Mite, Academic Press, London, pp. 161-167.

Butt TM, Jackson CW, Murugan W (2001). Fungi as Biocontrol Agents, Progress,Problems and Potentials. CBBS Publshing Co, UK, pp. 240-242.

Dangar TK, Geetha L, Jayapal SD, Pillai GB (1999). Mass Production of the Entomopathogens Metarhizium anisopliae in Coconut Water, J. Plant. Crop 19: 54-59.

Feng MG, Paponsk TJ, Kbachachiurians GG (1994). Production, Formulation and Application of the Entomopathogenic Fungus Beauveria bsssiana For Insect Control, Biocontrol Sci. Technol. 4: 531-544.

Gopalakrishnan C, Anusuya D, Narayanan K (1999) In vitro Production of Conidia of Entomopathogenic Fungus Parcilomyces farinosus, Entomology, 24: 389-392.

Gopalakrishnan C, Mohan SC (2000). A Simple and Cost Effective Invitro Method For the Mass Production of Conidia of Nomuraea rileyi, Insect Environ. 6: 52-53.

Humber RA (1997). Manual oj Techniques in Insect Pathology, Academic Pree, London pp. 153-155.

Ibrahim YB, Low W (1993). Potential of Mass Production and Field Efficacy of Isolates of the Entomopathoghenic Fungi Beauveria bassiana and Paecilomyces fumosoroseus on Plutella xylostella, J. Invertebr. Pathol. 39: 222-232.

Lakshmi SM, Alagammai PL, Jayaraj K (2001). Studies on Mass Culturing of the Entomopathogen Whitehalo Fungus Verticillium lecanii on Three Grain Media and Its Inefficacy on Helicoverpa armigera, In Igbachimuthu S, Sen S (eds.) Microbials In Insect Pest Management, Oxford and IBH publishing Pvt Ltd, New Delhi, pp. 2327.
Noris RF, Chen EPS, Kogn M (2002). Concepts in tegrated Pest Management. Premise Hall of India Private Limited, New Delhi.

Patel KC, Yadaw DV, Dube HC, abd Patel RJ (1990). Laboratory and Mass Production Studies With Metarhizium anisopliae, Annu. Biol. 6: 135-138.

Puzari KC, Sharma DK, Saranka LK (1997). Media fo Mass Production of Beauveria bassiana. J. Biol. Contr. 11: 96-100.

Romback MC (1989). Production of Beauveria bassinaa Conidia in Submerged Culture, Entomophaga, 5: 45-52.

Rousson S, Rainbautt M, Lonsane BK (1983). Zymotics a Large Scale Fermenter Design and Evaluation, Appl. Biochem. Biotechnol., 42: 161-167.

Sharma K (2004). Bionatural Mangement of Pests in Organic Farming, Agrobios Newsl. 2: 296-325.

Sharma SP, Gupta RBL, Yadava CPS (2002). Selection of a Suitable Medium For Mass Multipication of Entomofungal pathogens, Indian J. Entomol. 14(1): 255-261.

Tincilley A, Easwaramoorthy G, Santhanalakshmi G (2000.) Attempts on Mass Production of Nomuraea rileyi on Various Agricultural Products and Byproducts, J. Biol. Contr. 18(1): 33-40. 